\title{
Vitamin D Deficiency in HCV Antiviral Treatment Responders versus Non-Responders
}

\author{
Rana M Arif ${ }^{1}$, Fahad Aman Khan ${ }^{2}$, Imran Khan ${ }^{3}$, Muzammil Aslam Kataria ${ }^{4}$, Jawed lqbal ${ }^{5}$, Mukhtar Ahmed 6 \\ 1,4,5 Senior Registrar Medical Unit I, Jinnah Hospital Lahore \\ ${ }^{2}$ Assistant Professor Medicine, Medical Unit II, Allama Iqbal Medical College, Jinnah Hospital Lahore \\ ${ }^{3}$ Senior Registrar Medical Unit II, Jinnah Hospital Lahore \\ ${ }^{6}$ Assistant Professor Medical Unit II, Allama Iqbal Medical College Jinnah Hospital Lahore
}

\section{ABSTRACT}

\begin{abstract}
Background: Hepatitis $\mathrm{C}$ virus (HCV) is a major cause of chronic liver disease (CLD). Pakistan has a high burden of infectious diseases, including HCV. Its prevalence varies according to geographic regions in the country from about $2 \cdot 4 \%$ to $6 \cdot 5 \%$. The objective of the study was to compare the frequency of vitamin $\mathrm{D}$ deficiency in responders and non-responders of antiviral treatment for chronic hepatitis $\mathrm{C}$.
\end{abstract}

Material and Methods: This comparative cross-sectional study was conducted in Hepatitis Clinic, Jinnah hospital, Lahore from $20^{\text {th }}$ May to $20^{\text {th }}$ November 2013. After ethical approval, participants were selected by using purposive non-probability sampling, 52 responder patients i.e. who were labeled negative for HCV RNA by PCR after 12 weeks of antiviral treatment and 52 non-responder patients were included in this study. Data was collected by using pretested structured questionnaire. Vitamin D3 levels were measured by ELISA and a cut-off value of below $30 \mathrm{ng} / \mathrm{ml}$ was labeled as Vitamin D deficiency. SPSS version 21 was used to analyze data with $p$ value less than 0.05 taken as statistically significant.

Results: Out of 104 patients (mean age $35 \pm 8.1$ years), $61.5 \%$ were males and $38.5 \%$ were females. There was a significant difference in frequency of vitamin $D$ deficiency in treatment responder group when compared to non-responders $(p=0.016)$. Mean level of vitamin $D$ was $21.8 \pm 10.8 \mathrm{ng} / \mathrm{ml}$ in responders whereas it was $15.6 \pm 7.5$ in non-responders with a statistically significant difference $(p=0.001)$.

Conclusion: This study concludes that there is a significant vitamin $\mathrm{D}$ deficiency among treatment non-responders as compared to treatment responders in patients with chronic hepatitis $C$.

Key words: Vitamin D, Vitamin D deficiency, Viral Response

Authors' Contribution: Correspondence:

1-3 Conception, synthesis, planning of Rana Arif

research and manuscript writing Interpretation, discussion, ${ }^{-4-6}$ Data analysis, interpretation and manuscript writing, Active participation in data collection.

Cite this article: Arif MR, Khan FA, Khan I, Kataria MA, lqbal J, Ahmed M. Vitamin D deficiency in HCV antiviral treatment responders versus non-responders. J Islamabad Med Dental Coll.2019; 8(1):45-49
Article info:

Received: April 12, 2018

Email: rana-arif202@gmail.com Accepted: October 10, 2018

\section{Introduction}

Hepatitis $\mathrm{C}$ virus (HCV) is a major cause of chronic liver disease (CLD). It is a global dilemma and an alarming health issue with global incidence of 200 million (3.3\%). ${ }^{1}$ Pakistan also has a high burden of infectious disease including $\mathrm{HCV}^{2,3}$. Its prevalence varies according to geographic regions from about $2 \cdot 4 \%$ to $6 \cdot 5 \% .4,5$ However, very low rate of $\mathrm{HCV}$ is reported from developed nations like Canada $0.8 \%$, France $1.1 \%$, Germany $0.6 \%$, and Australia $1.1 \%$. Similarly, prevalence rate of HCV lower than Pakistan have also been reported from Italy $(2.2 \%)$ USA (1.8\%), Japan (12.3\%) and China (3.2\%) respectively. $6-10$ Whereas, Africa and Asia have the highest burden of HCV infection. Egypt alone with an estimated population of almost 73 million ${ }^{11}$ has a high 
seroprevalence rate of about $22 \% .{ }^{12}$ Liver is a vital organ for the metabolism of Vitamin D. It hydrolyzes vitamin $D$ from skin and diet into 25-hydroxyvitamin $D$ [25(OH)D] which can be estimated by ELISA ${ }^{13}$. Therefore, liver disease affect the metabolism of Vitamin $D$ leading to disturbance in calcium and bone metabolism. ${ }^{14}$ Deficiency of vitamin $D$ is associated with osteopenia, osteoporosis, osteomalacia and muscle weakness, resulting in higher chances of bone fractures. ${ }^{15}$ Moreover, Vitamin D deficiency is associated with multiple types of malignancies (e.g., prostate, colon, breast), as well as autoimmune inflammatory metabolic disorders. Vitamin D also plays a major role in calcium metabolism and in differentiation, proliferation and immunomodulation of cells. ${ }^{16}$ Similarly, Vitamin D deficiency resists fibroblastic proliferation and augments the production of collagen. HCV infection leads to Chronic Liver Disease (CLD) ${ }^{17}$ and eventually to hepatic fibrosis. ${ }^{18} \mathrm{It}$ is therefore essential to understand the role of vitamin $D$ deficiency in the treatment of chronic hepatitis $\mathrm{C}$, so that these patients may be screened and treated before starting the antiviral therapy.

\section{Material and Methods}

This comparative cross-sectional study was 'conducted in Hepatitis Clinic, Jinnah hospital, Lahore from $20^{\text {th }}$ May to $20^{\text {th }}$ November, 2013 after obtaining approval from the institutional ethics committee. Non-probability purposive sampling technique was used for sample collection. Patients of either sex of age 20-60 years, coming for follow up in hepatitis clinic of Jinnah Hospital Lahore were enrolled in this study. All patients had received 12-week treatment for chronic hepatitis $C$ i.e. conventional interferon injection and ribavirin tablets. Patient taking calcium/ Vitamin D supplementation, having advanced impaired liver and /or renal functions were excluded from the study.

After informed consent, 52 responders and 52 nonresponder patients were segregated into 2 groups. Data was collected using pretested structured questionnaire. Blood samples were collected using aseptic technique and vitamin D3 levels were assessed by Enzyme-Linked Immunosorbent Assay (ELISA). Genotype of HCV was also recorded to cater for effect modification. Data was entered and analyzed in SPSS version 21. Frequencies and percentages were calculated for qualitative variables while mean and standard deviation were computed for quantitative variables. Vitamin $D$ deficiency was compared in both groups i.e. responders and nonresponders using chi square test of homogeneity as a test of significance, with $p$ value less than or equal to 0.05 . Data was cross tabulated to determine the effect of age, sex and genotyping on treatment response and Vitamin D deficiency. Independent sample $t$ test and Chi square were used to rule out effect of these confounders. Vitamin $\mathrm{D}$ deficient patients were divided into two classes i.e. severe deficiency, if Vit $D$ level less was than $15 \mathrm{ng} / \mathrm{ml}$ and deficiency, if levels were between 15 and $30 \mathrm{ng} / \mathrm{ml}$. The difference in responders and non-responders was cross tabulated again.

\section{Results}

Out of 104 patients i.e. 52 responders and 52 nonresponders, patients with mean age of $35.3 \pm 8.1$ years were included. Mean vitamin D level came out to be 18.8 $\mathrm{ng} / \mathrm{ml} \pm 9.7$ (range 7.7 to $44 \mathrm{ng} / \mathrm{ml}$ ). There were $61.5 \%$ $(n=64)$ males and $38.4 \%(n=40)$ females, respectively. Genotype distribution showed 79 patients $(76 \%)$ with genotype 3, 19 Patients (18\%) had type 1 and only 6 patients (5.8\%) had type 2 genotype of hepatitis $C$ virus. Out of 104 patients 82 individuals (79\%) were vitamin D deficient. Mean level of vitamin $D$ was $21.8 \pm 10.8 \mathrm{ng} / \mathrm{ml}$ in responders while it was $15.6 \pm 7.5 \mathrm{ng} / \mathrm{ml}$ in nonresponders. Cross tabulation of vitamin $D$ deficiency categories and treatment response groups among Hepatitis C patients, showed significant difference of Vitamin $D$ Deficiency among treatment responders as compared to non-responders $(p=0.016)$ (Table I). Response to antiviral treatment is also significantly associated with genotype of Hepatitis $C(p=0.05)$. To rule out the effect of age and gender, we cross tabulated age groups of patients in both groups i.e. $>30$ years and $<30$ years and gender with treatment response, which showed that younger patients have a better response to treatment than older groups. There was no correlation of gender with treatment response $(p=0.314)$ (Table II). 


\begin{tabular}{|c|c|c|c|c|c|}
\hline \multicolumn{6}{|c|}{ Table I: Cross tabulation of Vit D deficiency and HCV genotypes with responder and non-responders } \\
\hline & & \multicolumn{2}{|c|}{ Groups } & \multirow[b]{2}{*}{ Total } & \multirow[b]{2}{*}{$P$ Value } \\
\hline & & Responders & Non-Responders & & \\
\hline \multirow[t]{2}{*}{ Vitamin D level } & Normal & 16 & 6 & 22 & \multirow[t]{2}{*}{ Pearson Chi square 0.016} \\
\hline & Deficient & 36 & 46 & 82 & \\
\hline \multirow[t]{3}{*}{ Genotypes } & Gen 3 & 45 & 34 & 79 & \multirow[t]{3}{*}{ Fisher's Exact 0.05} \\
\hline & Gen 2 & 2 & 4 & 6 & \\
\hline & Gen 1a or 1b & 5 & 14 & 19 & \\
\hline
\end{tabular}

\begin{tabular}{|c|c|c|c|c|c|}
\hline \multicolumn{6}{|c|}{$\begin{array}{l}\text { Table II: Cross tabulation of Vit D deficiency and HCV genotypes with responder and non-responders } \\
\qquad \mid \text { Groups }\end{array}$} \\
\hline & & Responders & Non-Responders & Total & $P$ Value \\
\hline \multirow[t]{2}{*}{ Gender } & Male & 29 & 35 & 64 & \multirow[t]{2}{*}{ Pearson Chi square 0.314} \\
\hline & Female & 23 & 17 & 40 & \\
\hline \multirow[t]{2}{*}{ Age group } & $>30$ years & 22 & 48 & 70 & \multirow[t]{2}{*}{ Fisher's Exact $<0.001$} \\
\hline & $<30$ years & 30 & 4 & 34 & \\
\hline
\end{tabular}

\begin{tabular}{|l|c|c|c|c|c|c|}
\hline \multicolumn{6}{|c|}{ Table III: Vitamin D levels in HCV treatment Responders and Non-Responders and different HCV genotypes } \\
\cline { 3 - 6 } \multicolumn{2}{|c|}{ Variables } & Severely deficient & Deficient & Normal & \multirow{2}{*}{ Total } & \multirow{2}{*}{ P Value } \\
\hline \multirow{2}{*}{ Study groups } & Responders & 22 & 14 & 16 & 52 & \multirow{2}{*}{ Pearson Chi square 0.026} \\
\cline { 2 - 6 } & Non-responders & 34 & 12 & 6 & 52 & \\
\hline \multirow{3}{*}{ HCV genotype } & Gen 3 & 43 & 21 & 15 & 79 & \multirow{3}{*}{ Fisher's Exact $<0.865$} \\
\cline { 2 - 6 } & Gen 2 & 3 & 1 & 2 & 6 & \\
\cline { 2 - 6 } & Gen 1a or 1b & 10 & 4 & 5 & 19 & \\
\hline
\end{tabular}

\begin{tabular}{|c|c|c|c|c|c|c|}
\hline \multirow{2}{*}{\multicolumn{2}{|c|}{ Variables }} & \multicolumn{2}{|c|}{ Groups } & \multirow[b]{2}{*}{ Normal } & \multirow[b]{2}{*}{ Total } & \multirow[b]{2}{*}{$P$ Value } \\
\hline & & Severely deficient & Deficient & & & \\
\hline \multirow{2}{*}{ Gender } & Male & 34 & 19 & 11 & 64 & \multirow{2}{*}{ Pearson Chi square 0.257} \\
\hline & Female & 22 & 7 & 11 & 40 & \\
\hline \multirow{2}{*}{ Age Grous } & $>30$ years & 43 & 18 & 9 & 70 & \multirow{2}{*}{ Pearson Chi square 0.01} \\
\hline & $<30$ years & 13 & 8 & 13 & 34 & \\
\hline
\end{tabular}

An inverse relationship of response to interferon therapy with Vitamin $D$ deficiency was also reported $(p=0.026)$. Severity of vitamin $D$ deficiency is not related to genotype and gender but is affected by age (Tables III and IV).

\section{Discussion}

The mean age of patients in our study shows that hepatitis has affected our population in the most productive age group. Similarly, vitamin $D$ deficiency is also very common involving almost $80 \%$ of our population. Genotype 3 is the main circulating viral genotype in our population, and is easily treatable. Our results also show higher frequency of Genotype 3 in treatment responders. Although previous studies showed that vitamin $D$ levels are not associated with sustained virologic response (SVR) to antiviral therapy (PEG-IFN and RBV) in hepatitis $C$ patients, but effect of Vitamin D supplementation on SVR was not clear. ${ }^{19}$ However, our study showed that Vitamin $D$ deficiency has significant negative correlation with response to hepatitis $C$ treatment; but the causal relationship cannot be elicited due to the limitation of the study design. Kitson et al reported mean $25(\mathrm{OH}) \mathrm{D}$ level of $79.6 \mathrm{nmol} / \mathrm{L}$, with $48 \%$ prevalence of $25(\mathrm{OH}) \mathrm{D}<75 \mathrm{nmol} / \mathrm{L}$ and $16 \%<50 \mathrm{nmol} / \mathrm{L}$ respectively in Chronic Hepatitis $\mathrm{C}$ genotype 1 patients. Their study showed no association of baseline $25(\mathrm{OH})$ level with SVR or fibrosis in HCV-1, but significant association with high activity grade. ${ }^{20}$ Similarly, Ladero et 
al also mentioned presence of vitamin $D$ deficiency among Spanish chronic hepatitis C patients. ${ }^{21}$ About 41 vitamin $D$ deficient patients were treated with vitamin $D$ supplements and later on re-evaluated. Vitamin D deficiency (<20ug/dl) was seen in $36.1 \%$ and suboptimal levels (20-30ug/dl) were observed in $40.9 \%$ patients. ${ }^{21}$

Our study findings are in agreement with Mohamed et al22 who reported low vitamin D levels in HCV patients as compared to the healthy population. Higher levels of Vitamin $D$ were observed among responders of ribavirin plus Pegylated interferon alpha 2a therapy while low levels were observed among non-responders. Therefore, it was concluded that vitamin $\mathrm{D}$ deficiency may contribute to delayed or unfavorable response of antiviral therapy in $\mathrm{HCV}$ infected patients.

Another study by Amanzada et al showed that lower pretreatment 25(OH)D levels and higher serum ferritin levels were significantly associated with fibrotic alteration and inflammatory activity. ${ }^{23} \mathrm{Yu}$ et al also reported significantly lower concentration of $25(\mathrm{OH}) \mathrm{D}$ in liver cirrhosis group than the control group with the conclusion that vitamin $\mathrm{D}$ might function as a protective factor against development of cirrhosis. ${ }^{24}$

Similarly, Villar et al reported in a systematic review that out of 1575 Hepatitis C patients, 1117 (71\%) were vitamin $D$ deficient. With respect to treatment, this systemic review had included 8 studies of both HCV persons without previous treatment and pooled patients with sustained viral response. In patients with very high SVR, Vitamin D levels was $>30 \mathrm{ng} / \mathrm{dl}$ which could be either supplemented or natural regardless of types of genotype. The results established high occurrence of vitamin $D$ deficiency in Hepatitis $C$ patients and SVR in persons with upper vitamin $\mathrm{D}$ levels or in patients getting vitamin $\mathrm{D}$ supplementation. ${ }^{25}$

\section{Conclusion}

There is a significant difference in vitamin $D$ levels among treatment responders and non-responders in patients with chronic Hepatitis $\mathrm{C}$, with a very low rate of vitamin D observed among non-responders. Severity of vitamin $D$ deficiency is not related to genotype and gender but is affected by age. It is hereby recommended to screen every patient before the start of antiviral treatment for a better outcome of Hepatitis treatment.

\section{References}

1. Saeed M, Iram S, Hussain S, Mobeen R, Ahmad M, Ashraf $M$. Heatitis $C$ in asymptomatic population. TPMJ. 2016;2(5): 546-552

2. Saeed M, Hussain S, Rasheed F, Ahmad M, Arif M, Rahmani MTH. Silent killers: Transfusion transmissible infections-TTI, among asymptomatic population of Pakistan. J Pak Med Assoc. 2017;67(3):369-74.

3. Shazad $f$, saeed $m$. Comparison between elisa and ict techniques for the detection of anti HCV antibody among blood donors. Biomedica. 2016;32(4):281-4.

4. Gower E, Estes C, Blach S, Razavi-Shearer K, Razavi H. Global epidemiology and genotype distribution of the hepatitis $C$ virus infection. J hepatol. 2014;61(1): S45-S57.

5. Khattak M, Salamat N, Bhatti F, Qureshi T. Seroprevalence of hepatitis B, C and HIV in blood donors in northern Pakistan. J Pak Med Assoc. 2002;52(9):398-402.

6. Alter MJ, Kruszon-Moran D, Nainan OV, McQuillan GM, Gao F, Moyer LA, et al. The prevalence of hepatitis $C$ virus infection in the United States, 1988 through 1994. N Engl J Med. 1999;341(8):556-62.

7. Ohshima S, Komatsu M, Nakane K, Meng XW, Goto $T$, Fujii $T$, et al. latrogenic $G B$ virus $C /$ hepatitis $G$ virus infection in an area endemic for hepatitis $C$ virus. $J$ Hosp Infect. 2000;44(3):179-85.

8. Ito SI, Ito M, Cho MJ, Shimotohno K, Tajima K. Massive Sero-epidemiological Survey of Hepatitis C Virus: Clustering of Carriers on the Southwest Coast of Tsushima, Japan. Cancer Science. 1991;82(1):1-3.

9. Hayashi J, Nakashima K, Yoshimura E, Hirata M, Maeda $\mathrm{Y}$, Kashiwagi S. Detection of HCV RNA in subjects with antibody to hepatitis $C$ virus among the general population of Fukuoka, Japan. J gastroenterol. 1994;29(2):147-51.

10. Puro V, Petrosillo N, Ippolito G, Aloisi MS, Boumis E, Rava L. Occupational hepatitis $C$ virus infection in Italian health care workers. Italian Study Group on Occupational Risk of Bloodborne Infections. Am J Public Health. 1995;85(9):1272-5.

11. Mujeeb S, Shahab S, Hyder A. Geographical display of health information: study of hepatitis $C$ infection in Karachi, Pakistan. Public health. 2000;114(5):413-5. 
12. Frank C, Mohamed MK, Strickland GT, Lavanchy D, Arthur RR, Magder LS, et al. The role of parenteral antischistosomal therapy in the spread of hepatitis $\mathrm{C}$ virus in Egypt. The Lancet. 2000;355(9207):887-91.

13. Christakos S, Dhawan $P$, Verstuyf $A$, Verlinden $L$, Carmeliet G. Vitamin D: metabolism, molecular mechanism of action, and pleiotropic effects. Physiological reviews. 2015;96(1):365-408.

14. Mann MC, Hobbs AJ, Hemmelgarn BR, Roberts DJ, Ahmed SB, Rabi DM. Effect of oral vitamin D analogs on mortality and cardiovascular outcomes among adults with chronic kidney disease: a meta-analysis. Clin Kidney J. 2015;8(1):41-8.

15. Bikle DD. Vitamin D metabolism, mechanism of action, and clinical applications. Chem Biol. 2014;21(3):319-29.

16. Lewiecki EM. Osteoporosis: clinical evaluation. Endotext [Internet]: MDText. com, Inc.; 2018.

17. Yaşar E, Adigüzel E, Arslan M, Matthews DJ. Basics of bone metabolism and osteoporosis in common pediatric neuromuscular disabilities. Eur J Paediatr Neurol. 2018;22(1):17-26.

18. Taguba AQ, Velasco MDS, Panlilio MTT, Rubio MJM, Villamayor MEJ, Ong JP, et al. PO-028: Prevalence of Vitamin D Deficiency in Chronic Liver Disease at the Outpatient Clinics of the University of the Philippines-Philippine General Hospital. 춘. 추계 학술대회 (KASL). 2016;2016(1):93-.

19. Kitson MT, Sarrazin C, Toniutto P, Eslick GD, Roberts SK. Vitamin D level and sustained virologic response to interferon-based antiviral therapy in chronic hepatitis C: a systematic review and meta-analysis. J hepatol. 2014;61(6):1247-52.

20. Kitson MT, Dore GJ, George J, Button P, McCaughan GW, Crawford DH, et al. Vitamin D status does not predict sustained virologic response or fibrosis stage in chronic hepatitis $\mathrm{C}$ genotype 1 infection. J Hepatol. 2013;58(3):467-72.

21. Ladero JM, Torrejón MJ, Sánchez-Pobre $P$, Suárez $A$, Cuenca $F$, de la Orden $V$, et al. Vitamin $D$ deficiency and vitamin $D$ therapy in chronic hepatitis C. Ann Hepatol. 2013;12(2):199-204.

22. Mohamed A, Sabry N, Abbassi M, Ibrahim W, AliEldin Z. Vitamin D levels in Egyptian HCV patients (genotype 4) treated with PEGylated interferon. Acta gastro-enterologica Belgica. 2013;76.

23. Amanzada A, Goralczyk AD, Moriconi F, van Thiel DH, Ramadori G, Mihm S. Vitamin D status and serum ferritin concentration in chronic hepatitis $C$ virus type 1 infection. J. Med. Virol. 2013;85(9):153441.

24. Yu L, Yin L, Chen W, Fan J, Cui J, Yin J, et al. Prospective study on the relation between serum vitamin $\mathrm{D}$ levels and liver cirrhosis risk. Zhonghua gan zang bing za zhi= Zhonghua ganzangbing zazhi= Chinese J hepatol. 2013;21(3):202-6.

25. Villar LM, Del Campo JA, Ranchal I, Lampe E, Romero-Gomez M. Association between vitamin D and hepatitis $C$ virus infection: a meta-analysis. World Journal of Gastroenterology: WJG. 2013;19(35):5917. 